\title{
OCCURRENCE OF ANTIBODY TO SALIVARY DUCT EPITHELIUM IN SJØGREN'S DISEASE, RHEUMATOID ARTHRITIS, AND OTHER ARTHRITIDES A CLINICAL AND LABORATORY STUDY
}

BY

R. N. M. MACSWEEN, R. B. GOUDIE, J. R. ANDERSON*, E. ARMSTRONG $\dagger$, M. A. MURRAY, D. K. MASON, M. K. JASANI, J. A. BOYLE, W. W. BUCHANAN, AND J. WILLIAMSON

From the University Department of Pathology, Western Infirmary, and The Centre for Rheumatic Diseases, Baird Street, Glasgow

Sjøgren's disease, first described in 1933 (Sjøgren, 1933), consists of chronic inflammation of the lacrimal and salivary glands leading to dryness of the eyes (keratoconjunctivitis sicca) and dryness of the mouth (xerostomia); in a proportion of patients lacrimal and salivary gland enlargement may also be present (Bloch, Buchanan, Wohl, and Bunim, 1965; Talal, 1966). In 50 to 60 per cent. of patients the disease may be associated with a connective tissue disorder, usually rheumatoid arthritis, but occasionally also with polymyositis, polyarteritis nodosa, progressive systemic sclerosis (scleroderma), and systemic lupus erythematosus. The term "sicca syndrome" or "sicca complex" is applied to those cases of Sjøgren's disease not associated with rheumatoid arthritis or other connective tissue disorders.

In Sjøgren's disease, even in the absence of rheumatoid arthritis or other connective tissue disease (i.e. the sicca syndrome), there is hypergammaglobulinaemia and a high incidence of abnormal immunological reactions, such as antinuclear factors, rheumatoid factors, precipitating antibodies to tissue constituents, autoimmune complement-fixation tests, and passive cutaneous anaphylaxis in guinea-pigs (Jones, 1958; Stoltze, Hanlon, Pease, and Henderson, 1960; Anderson, Gray, Beck, and Kinnear, 1961; Anderson, Gray, Beck, Buchanan, and McElhinney, 1962; Bunim, Buchanan, Wertlake, Sokoloff, Bloch, Beck, and Alepa, 1964; Beck, Anderson, Bloch, Buchanan, and Bunim, 1965; Bloch and others, 1965). In addition to these non-organ specific reactions, the

\footnotetext{
* Present address-Department of Pathology, The University of Liverpool.

$\dagger$ Medical Student
}

prevalence of low titre thyroid auto-antibodies is slightly higher than expected (Anderson, Goudie, Gray, and Buchanan, 1961 ; Bloch and others, 1965) and gastric parietal cell auto-antibodies with chronic atrophic gastritis show a higher prevalence, at least in patients studied in Glasgow (Buchanan, Cox, Harden, Glen, Anderson, and Gray, 1966). These serum factors indirectly favour the view that Sjøgren's disease may have an autoimmune basis.

Bertram and Halberg (1964) and Halberg, Bertram, Søborg, and Nerup (1965) reported the demonstration by immunofluorescence of antibody against salivary duct epithelium in eleven of nineteen patients with Sjøgren's disease, and they considered that the antigen might be organ specific, i.e. peculiar to salivary tissue. In the present paper we report the incidence of this salivary duct antibody (SDA) in groups of patients with the sicca syndrome (Sc), patients with Sjøgren's disease complicated by rheumatoid arthritis ( $\mathrm{Sj}-\mathrm{RA})$, patients with rheumatoid arthritis alone (RA) and patients with various other arthritides. The presence of the antibody has been further studied in relation to a number of clinical and laboratory findings.

\section{Materials and Methods}

\section{Patients}

231 patients were studied. The clinical diagnosis, sex distribution, mean age, and age range are shown in Table I (opposite).

The diagnosis of Sjøgren's disease was based on the criteria described by Bloch and others (1965), and patients were required to show at least two of the three major components of the syndrome. The diagnosis of rheumatoid arthritis was based on the criteria of the American Rheumatism Association (Ropes, Bennett, Cobb, Jacox, and Jessar, 1958). 
TABLE I

INCIDENCE OF SALIVARY DUCT ANTIBODY IN VARIOUS CONDITIONS

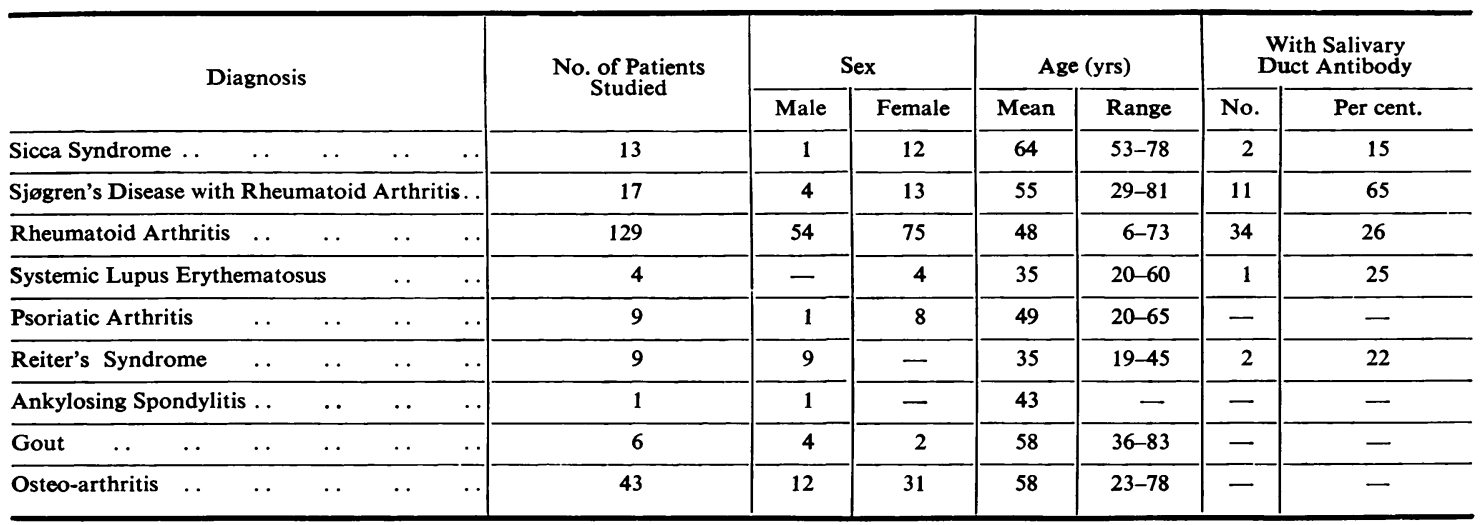

\section{Ophthalmological Examination}

This was performed by the method described by Williamson, Cant, Mason, Greig, and Boyle (1967). Each patient was examined for evidence of keratoconjunctivitis sicca by one of us (J.W.) who was unaware of the clinical diagnosis. A Schirmer I tear test was carried out using standardized sterile paper strips developed by Halberg and Berens (Contactisol Inc., Lindenhurst, New York, U.S.A.) in an atmosphere between $60-70^{\circ} \mathrm{F}$. with a relative humidity greater than 40 (Williamson and Allison, 1967). Wetting of the filter paper was read after 5 minutes and the mean of the two eyes recorded. Patients with wetting exceeding $15 \mathrm{~mm}$. were considered normal and were not examined further. Those with wetting less than $15 \mathrm{~mm}$. had a Schirmer II tear test and a Rose Bengal dye test performed. The Schirmer II test consisted of repeating the Schirmer I test while exposing the patient to a 10 per cent. solution of ammonia held 6 inches from the nose for 5 minutes. The Rose Bengal test consisted of instilling a 1 per cent. solution of the dye into the conjunctival sacs, followed immediately by irrigation with normal saline, and by examination with a Zeiss or Haag-Streit slit lamp for punctate and/or filamentary keratitis. Staining in the area previously in contact with the Schirmer paper was ignored.

A "definite" diagnosis of keratoconjunctivitis sicca was diagnosed when either the Schirmer I or Schirmer II test showed wetting less than $15 \mathrm{~mm}$. but more than $5 \mathrm{~mm}$., and the Rose Bengal dye test showed at the most only faint staining of the conjunctivae. Patients with a "possible" diagnosis did not have punctate and/or filamentary keratitis on slit-lamp examination.

Each patient was carefully questioned regarding a history of xerostomia and of associated oral and pharyngeal symptoms of Sjøgren's disease (Bloch and others, 1965). Salivary flow studies were performed using a modified Carlson-Crittenden cup with an outer chamber diameter of $20 \mathrm{~mm}$. and an inner chamber diameter of
$10 \mathrm{~mm}$. Parotid saliva was collected from each patient under resting condition and after stimulation with fruit gums and lemon juice.

Many patients admitted to having a dry mouth (symptomatic xerostomia) but without experiencing insufficiency of saliva and/or difficulty in mastication, or requiring increased fluid intake. Their mouths appeared to be moist and salivary flow studies on a sample of them were within the normal range.

Sialography was performed on all the 231 patients, using the hydrostatic technique described by Park and Mason (1966). The criteria of abnormality in the sialograms were based on those described by Bloch and others (1965).

\section{Other Clinical and Laboratory Data}

In addition to the age and sex of the patient and the ophthalmological and oral examinations described, the following clinical facts were recorded:

Duration of arthritis, presence of subcutaneous nodules, functional grade, and $x$-ray classification (Steinbrocker, Traeger, and Batterman, 1949).

Laboratory investigations included:

Haemoglobin concentration, erythrocyte sedimentation rate (Westergren), white cell count, and assay of serum globulin.

\section{Serological Methods}

Salivary Duct Antibody (SDA).-Blocks of human submandibular gland obtained at autopsy not more than 10 hours after death were frozen on to metal chucks with $\mathrm{CO}_{2}$ snow and $6 \mu$ sections were cut in a cryostat. The sera were applied undiluted to the unfixed section for 30 minutes at room temperature. After washing in normal saline buffered with veronal $(\mathrm{pH} \mathrm{7 \cdot 2)}$ for 10 minutes, fluorescein-conjugated goat anti-human globulin serum was applied for 30 minutes. After a final 10 minutes 
wash in buffered saline the sections were mounted in buffered glycerol and examined with a Gillett and Sibert conference microscope using blue light. To reduce nonspecific fluorescent staining, the fluorescein-conjugated anti-human globulin serum was absorbed twice with dried rat liver powder.

Anti-nuclear Factor ( $A N F$ ) was detected using the indirect fluorescence method described by Beck (1961) with rat liver as substrate. The sera were initially tested at a dilution of 1 in 16 and positive sera were then titrated in quadrupling dilutions till an end point of nuclear staining was obtained.

Anti-thyroglobulin was detected by the tanned red cell haemagglutination test described by Fulthorpe, Roitt, Doniach, and Couchman (1961), using thyroglobulincoated formolized tanned sheep red cells (Burroughs Wellcome). The sera were initially tested at a dilution of 1 in 16 and positive sera were titrated in quadrupling dilutions.

Thyroid "Microsomal" Antibody was detected by the indirect immunofluorescence technique described by Holborow, Brown, Roitt, and Doniach (1959), using unfixed thyrotoxic thyroid tissue as substrate and with the test sera diluted 1 in 4 .

Gastric Parietal Cell Antibodies were demonstrated by an indirect immunofluorescence technique (Adams, Glen, Kennedy, Mackenzie, Morrow, Anderson, Gray, and Middleton, 1964), using unfixed human gastric mucosa as substrate and testing the sera undiluted.

In the tests for SDA a highly reactive fluoresceinconjugated goat anti-human globulin provided by $\mathrm{Dr}$. J. S. Beck was used, while in the other immunofluorescent tests commercially available fluorescein-conjugated rabbit anti-human globulin (Burroughs Wellcome) was used.

Rheumatoid Factor was determined by the Hyland latex (RA) test technique (Hyland Laboratories, California). All sera were screened at a dilution of 1 in 32 and the presence of agglutination was recorded 15 and 45 seconds after mixing the reagents. Agglutination at either 15 or 45 seconds was recorded as positive. Positive sera were then titrated in doubling dilutions.

Non-specific Tissue Precipitin Tests were performed, using the method described by Anderson, Gray, and others (1961) with human thyroid tissue as antigen. All specimens were tested undiluted and at a dilution of 1 in 8.

\section{Results}

Fig. 1 (opposite) shows positive and negative staining of salivary duct epithelium. Positive immunofluorescent staining varied in intensity, but even with the brightest staining pattern it was found that the antibody was present in low titre, none exceeding 1 in 32 .
In the following statistical analysis $\chi^{2}$ has been calculated (when appropriate) using Yates's correction for small numbers. Comparisons which do not yield statistically significant differences are not discussed.

\section{Whole Series: Incidence of SDA in Various Conditions} (Table I, see p. 403).

In patients with Sc, the antibody was found in only two of thirteen (15 per cent.). In contrast, the antibody was present in eleven of seventeen patients (65 per cent.) with $\mathrm{Sj}$ RA. In the RA group 34 of 129 patients (26 per cent.) had SDA in their serum, an incidence not differing significantly from that found in the Sc group, but lower than that in the Sj-RA group $\left(\chi^{2}=12 \cdot 23 ; \mathrm{P}<0.001\right)$.

Of the various other groups examined, one of the four patients with systemic lupus erythematosus and two of nine males with Reiter's syndrome had SDA.

The patient with systemic lupus had definite keratoconjunctivitis sicca, severe xerostomia with objective evidence of reduced salivary flow rate, punctate sialectasis and intermediate duct changes on sialography, and a history of intermittent parotid swelling. Of the two patients with Reiter's syndrome, one had definite keratoconjunctivitis sicca, but no other stigmata of Sjøgren's disease were found.

None of the 43 patients with osteo-arthritis was found to have SDA.

Sc and Sj-RA Groups (Tables II and III, overleaf)

Patients with Sj-RA had SDA more often than did those with Sc $\left(\chi^{2}=5.43 ; \mathrm{P}<0.02\right)$. The two groups also differed in that the Sc patients were older $(t=3.89 ; \mathrm{P}<0.001)$, and had more sialographic abnormalities $\left(\chi^{2}=12.6 ; \mathrm{P}<0.001\right)$ and $\mathrm{a}$ lower erythrocyte sedimentation rate $(t=3 \cdot 47$;

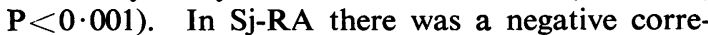
lation between SDA and ANF $\left(\chi^{2}=8 \cdot 24\right.$; $\mathrm{P}<0.01)$.

RA Group (Tables IV and V, Fig. 2, overleaf)

SDA was found significantly more frequently in older rheumatoid patients and in those with more severe rheumatoid disease as judged by functional grade, $x$ ray stage, erythrocyte sedimentation rate, and the prevalence of rheumatoid factor. As shown in Fig. 2, the prevalence of rheumatoid factor for all titres except 1 in 32 as well as the highest titres were seen in SDA positive patients. 
(a)
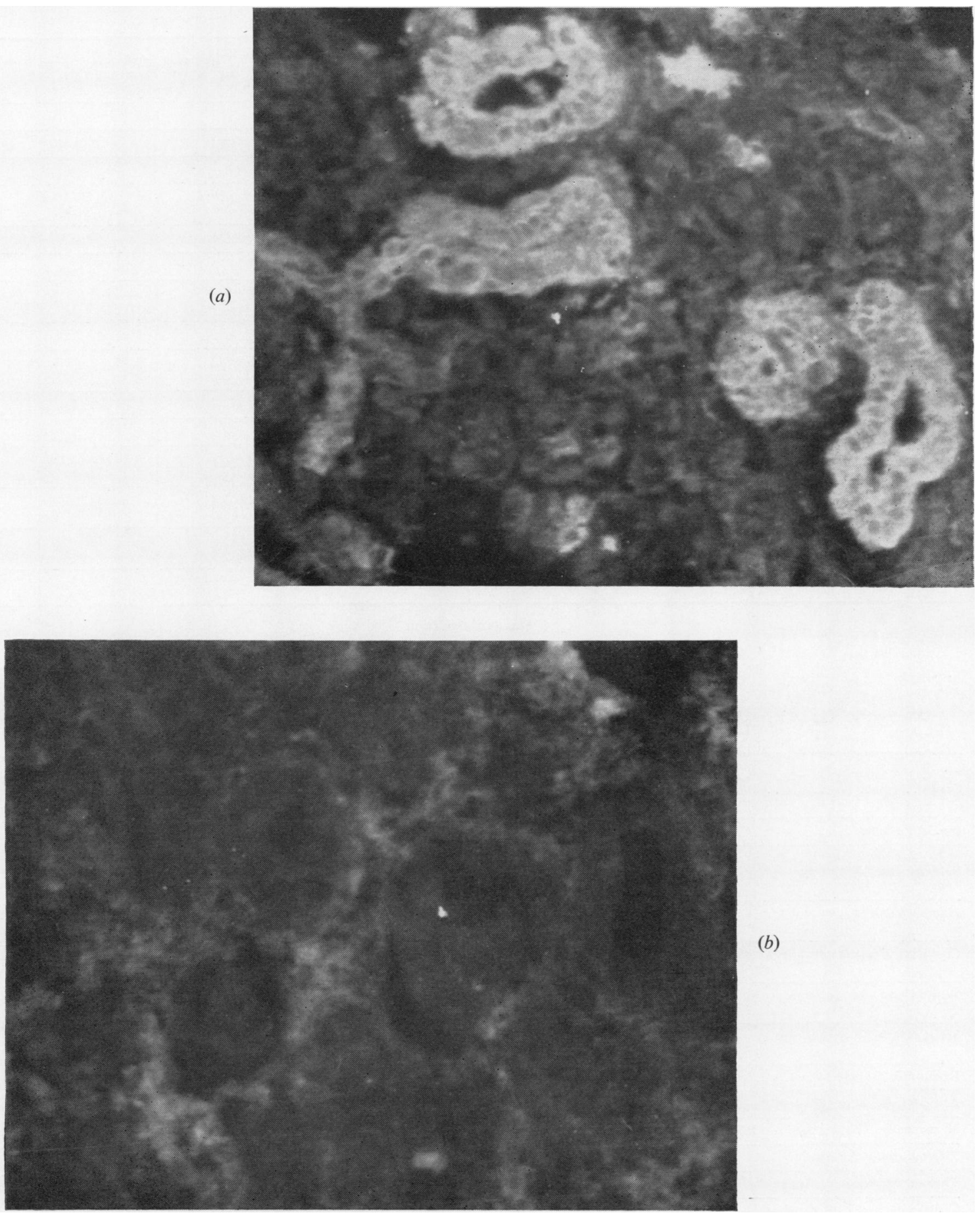

(b)

Fig. 1.-Frozen sections of human submandibular gland stained by indirect immunofluorescence

(a) With a serum containing salivary duct antibody: there is brilliant fluorescence of the duct epithelium, while the nuclei remain dark.

(b) With a normal serum: the ductal elements are just outlined 
TABLE II

CLINICAL FINDINGS IN PATIENTS WITH SJøGREN'S DISEASE

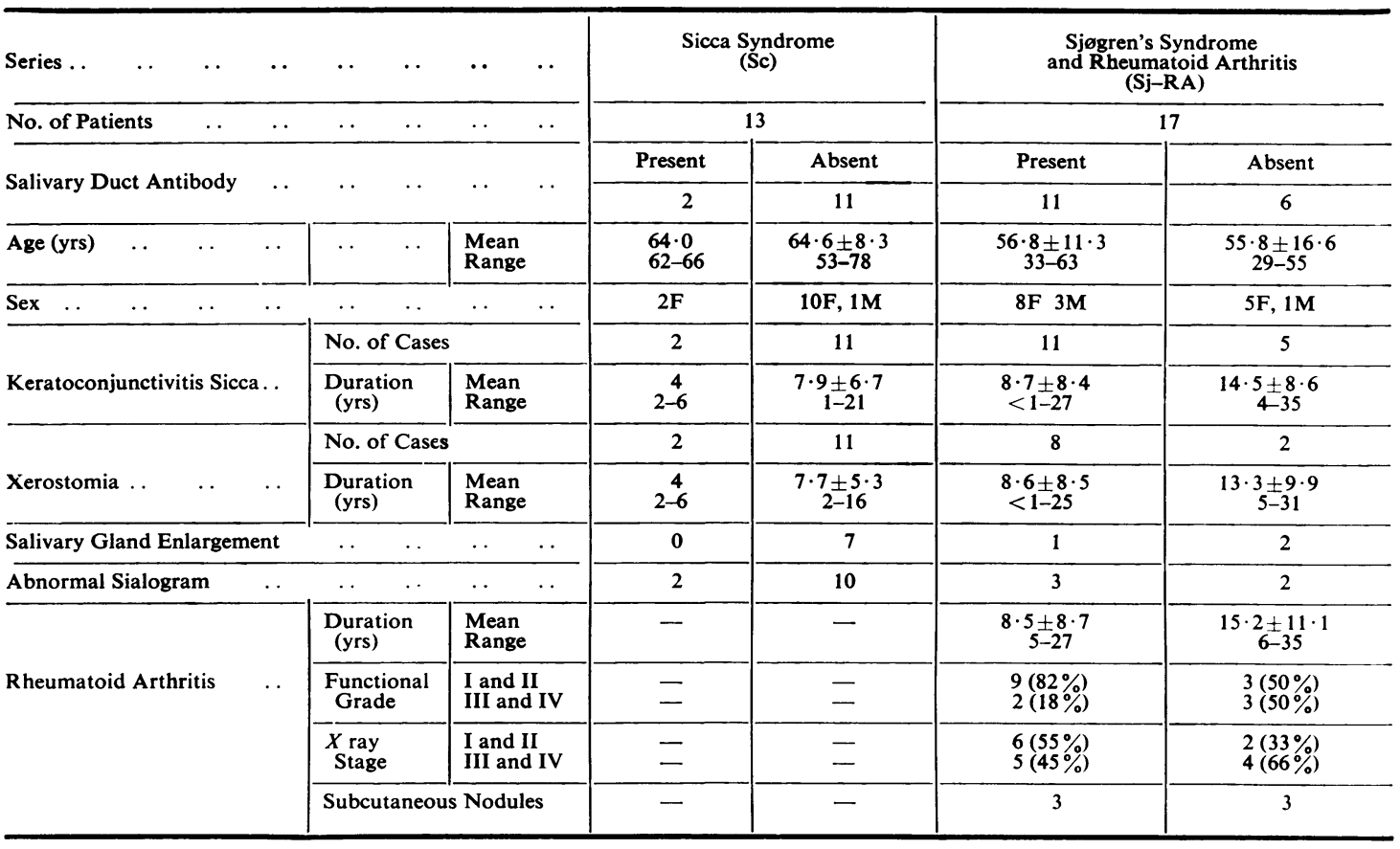

\pm Standard deviation

TABLE III

LABORATORY FINDINGS IN PATIENTS WITH SJØGREN'S DISEASE

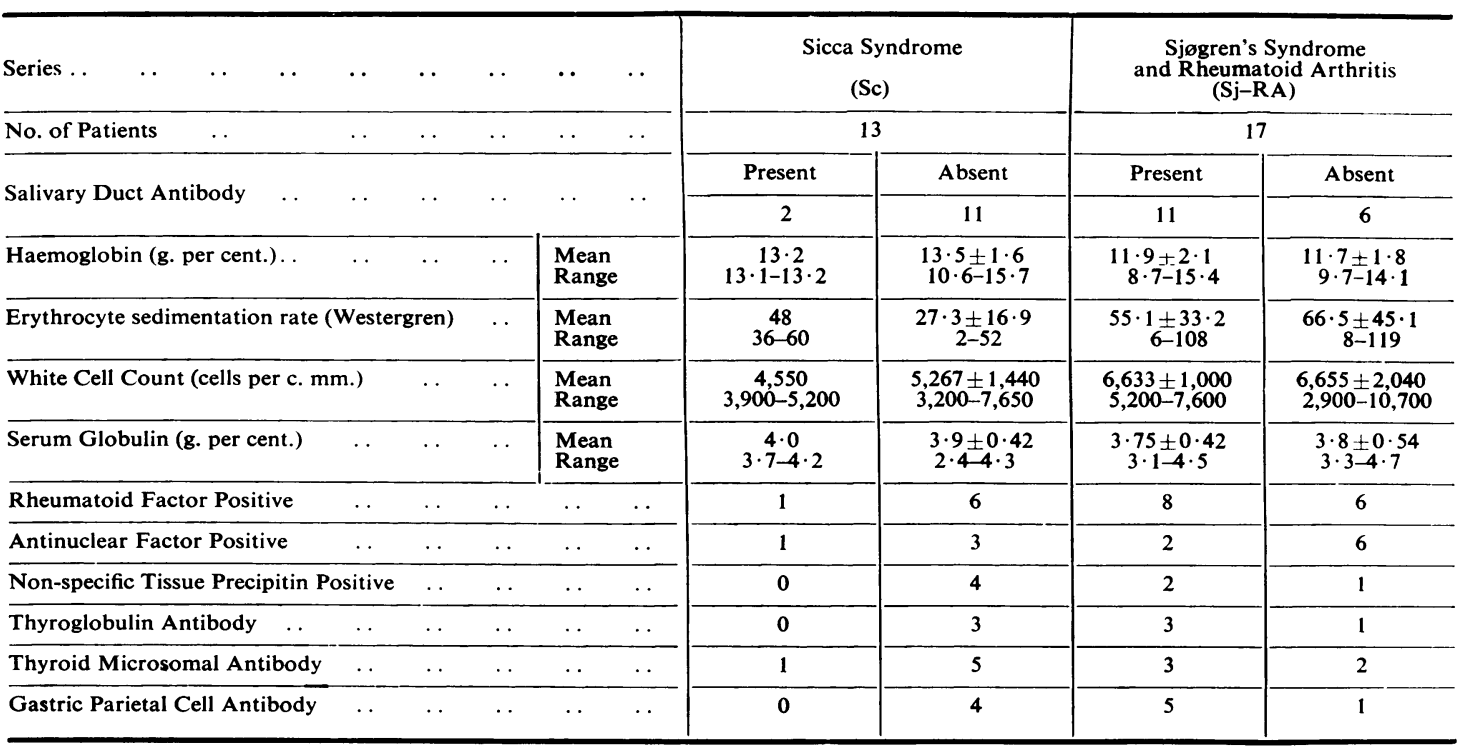


TABLE IV

RELATIONSHIPS BETWEEN SALIVARY DUCT ANTIBODY AND CLINICAL FINDINGS IN 129 PATIENTS WITH RHEUMATOID ARTHRITIS

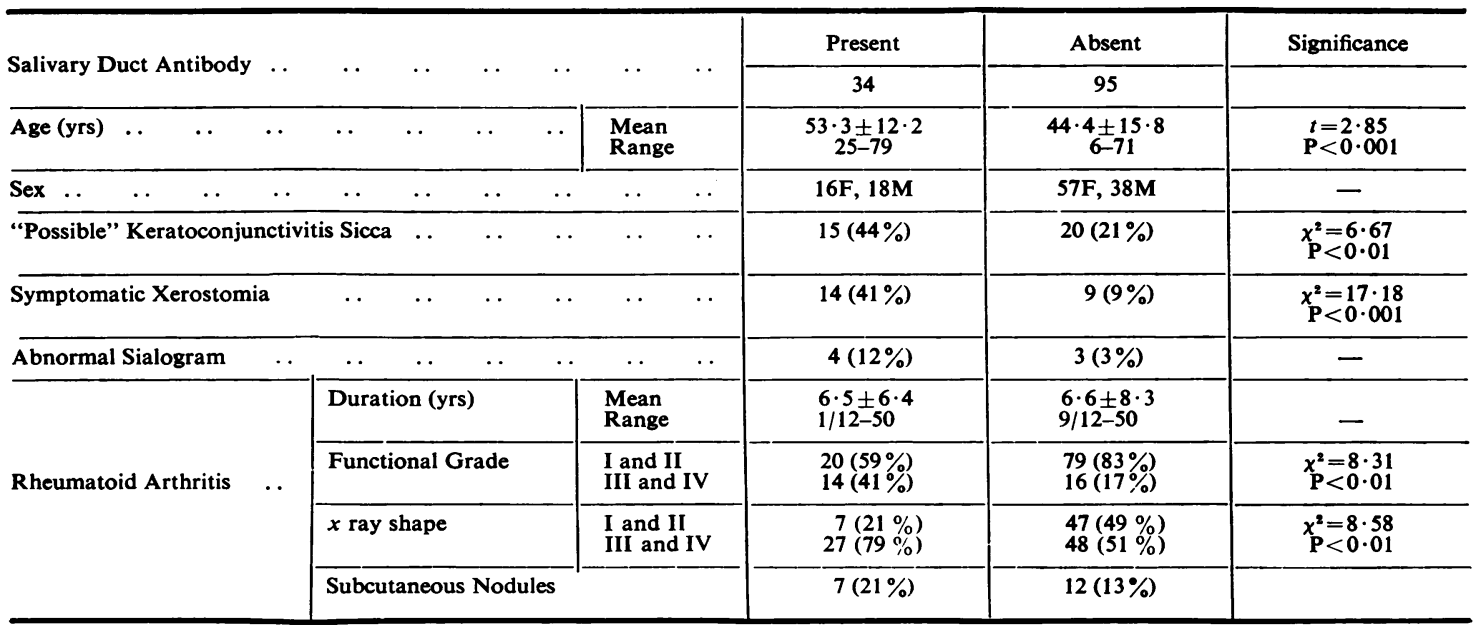

\pm Standard deviation

TABLE V

RELATIONSHIPS BETWEEN SALIVARY DUCT ANTIBODY AND LABORATORY FINDINGS IN 129 PATIENTS WITH RHEUMATOID ARTHRITIS

\begin{tabular}{|c|c|c|c|c|c|c|c|c|}
\hline \multirow{2}{*}{ Salivary Duct Antibody } & \multirow{2}{*}{$\cdots$} & \multirow{2}{*}{$\cdots$} & \multirow{2}{*}{$\cdots$} & \multirow{2}{*}{$\cdots$} & \multirow{2}{*}{$\cdots$} & \multirow{2}{*}{$\begin{array}{c}\text { Present } \\
34\end{array}$} & \multirow{2}{*}{$\begin{array}{c}\text { Absent } \\
95\end{array}$} & \multirow[t]{2}{*}{ Significance } \\
\hline & & & & & & & & \\
\hline Haemoglobin (g. per cent.) & . & $\cdots$ & $\ldots$ & $\ldots$ & $\begin{array}{l}\text { Mean } \\
\text { Range }\end{array}$ & $\begin{array}{l}12 \cdot 9 \pm 1 \cdot 6 \\
8 \cdot 1-16 \cdot 2\end{array}$ & $\begin{array}{r}12 \cdot 8 \pm 1 \cdot 9 \\
8 \cdot 6-17 \cdot 0\end{array}$ & - \\
\hline $\begin{array}{l}\text { Erythrocyte sedimentation rate } \\
\text { (Westergren) }\end{array}$ & $\cdots$ & . & $\cdots$ & $\cdots$ & $\begin{array}{l}\text { Mean } \\
\text { Range }\end{array}$ & $\underset{5-114}{50 \pm 30 \cdot 1}$ & $\begin{array}{c}33 \pm 27 \cdot 2 \\
2-125\end{array}$ & $\begin{array}{l}t=2.94 \\
\mathrm{P}<0.001\end{array}$ \\
\hline Serum Globulin (g. per cent.) & $\cdots$ & $\cdots$ & . & . & $\begin{array}{l}\text { Mean } \\
\text { Range }\end{array}$ & $\begin{array}{l}3 \cdot 9 \pm 1 \cdot 2 \\
2 \cdot 4-4 \cdot 6\end{array}$ & $\begin{array}{c}3 \cdot 37 \pm 0 \cdot 6 \\
1 \cdot 9-4 \cdot 9\end{array}$ & - \\
\hline Rheumatoid Factor Positive & $\cdots$ & . & $\cdots$ & $\cdots$ & . & $29(85 \cdot 3 \%)$ & $43(45 \cdot 2 \%)$ & $\begin{array}{l}x^{2}=16.27 \\
P<0.001\end{array}$ \\
\hline Anti-nuclear Factor Positive & $\cdots$ & $\cdots$ & $\cdots$ & $\cdots$ & $\cdots$ & $13(38 \%)$ & $20(21 \%)$ & 一 \\
\hline Non-specific Tissue Precipitins $P$ & Positive & e.. & $\cdots$ & $\cdots$ & $\cdots$ & $1(3 \%)$ & $4(4 \%)$ & - \\
\hline Thyroglobulin & $\ldots$ & $\cdots$ & $\cdots$ & $\cdots$ & $\ldots$ & $3(9 \%)$ & $7(7 \%)$ & 一 \\
\hline Thyroid Microsomal Autoantibc & ody & $\cdots$ & $\cdots$ & $\cdots$ & $\cdots$ & $8(23 \%)$ & $17(18 \%)$ & - \\
\hline Gastric Parietal Cell Antibody & $\cdots$ & . & . & . & $\ldots$ & $9(26 \%)$ & $11(11 \%)$ & - \\
\hline
\end{tabular}




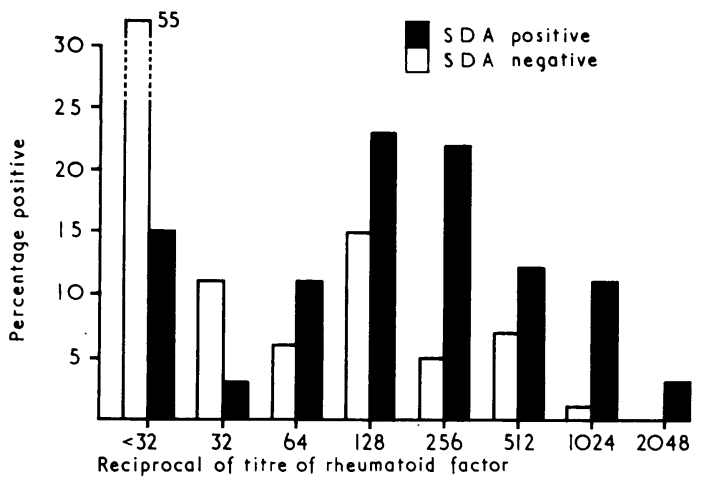

Fig. 2.-Histogram showing percentage of cases positive for rheumatoid factor in patients with rheumatoid arthritis with or without salivary duct antibody

A higher incidence of "possible" keratoconjunctivitis sicca and of symptomatic xerostomia was found in those with SDA. Table VI compares the frequency of "possible" keratoconjunctivitis sicca, symptomatic xerostomia, and abnormal sialograms in rheumatoid patients and in those with other rheumatic diseases-psoriatic arthritis, Reiter's syndrome, ankylosing spondylitis, gout, and osteoarthritis. There is no significant difference. The sub-group of rheumatoid patients with SDA had symptomatic xerostomia more frequently than other patients $\left(\chi^{2}=6 \cdot 4 ; P<0 \cdot 01\right)$.

\section{Comparison of Sj-RA and RA Groups}

Among all the patients with rheumatoid arthritis, $\mathrm{Sj}-\mathrm{RA}$ was found in those who were older $(t=2 \cdot 1$; $\mathrm{P}<0.05)$, had had their arthritis for a longer period $(t=1.98 ; \mathrm{P}<0.05)$, and had more severe rheumatoid disease as judged by the erythrocyte sedimentation rate $(t=3.5 ; \quad \mathrm{P}<0.02)$ and the presence of subcutaneous nodules $\left(\chi^{2}=4 \cdot 5\right.$; $\mathbf{P}<0.05)$. The Sj-RA group also had a higher prevalence of SDA $\left(\chi^{2}=12.23 ; \mathrm{P}<0.001\right)$ and of rheumatoid factor $\left(\chi^{2}=4 \cdot 37 ; \mathrm{P}<0.05\right)$.

Similarly, when $\mathrm{Sj}$-RA patients were compared with SDA-positive RA patients, the former were shown to have had their arthritis longer $(t=1 \cdot 73$; $P<0.05)$ and to have a higher erythrocyte sedimentation rate $(t=2.4 ; \mathrm{P}<0.02)$. No age difference was, however, found.

\section{Discussion}

Bertram and Halberg (1964) first described the occurrence in Sjøgren's disease of an antibody against salivary duct epithelium. Since sera containing the antibody did not give immunofluorescent staining of salivary gland acini or of thyroid, they considered that the antibody might be specific for an antigen peculiar to salivary duct epithelium. Feltkamp (1967) has shown that the antibody could be absorbed from the serum with extracts of salivary gland, but extracts of a number of other tissues, including thyroid, liver, and kidney, failed to do so.

We have shown that the antibody reacts with the individual's own tissues (i.e. it is an autoantibody) and also causes immunofluorescent staining of small lacrimal ducts, but not of gastric, thyroid, or prostatic epithelium. The mitochondral antibody found in a high percentage of patients with primarys biliary cirrhosis (Walker, Doniach, Roitt, and Sherlock, 1965; Goudie, Macsween, and Goldberg, 1966) gives an immunofluorescent staining pattern with salivary gland similar to that seen with SDA positive sera. Preliminary experiments, however, have shown that the SDA differs from the mitochondrial antibody in that only the latter can be absorbed from sera with rat liver mitochondria. The SDA thus shows some organ-specificity, but final confirmation must await further experimental investigation.

In our present studies we have found SDA in 15 per cent. of patients with Sc, but in 65 per cent. of

TABLE VI

"POSSIBLE" KERATOCONJUNCTIVITIS SICCA, SYMPTOMATIC XEROSTOMIA, AND ABNORMAL SIALOGRAMS IN RHEUMATOID ARTHRITIS AND IN OTHER ARTHRITIDES

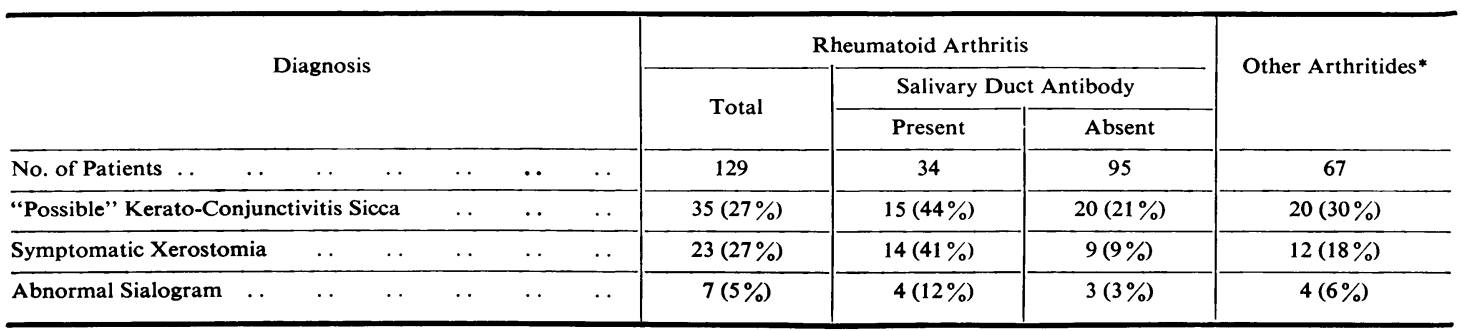

*Other arthritides = psoriatic arthritis, Reiter's syndrome, ankylosing spondylitis, gout, and osteo-arthritis. 
patients with Sj-RA. In RA the incidence of the antibody was 26 per cent. In none of the large series of patients with osteo-arthritis was the antibody present. The antibody is thus not peculiar to Sjøgren's disease. It is most commonly found in $\mathrm{Sj}-\mathrm{RA}$, but is also present in one in four of patients with RA, and in one in seven of Sc patients. These observations suggest that the antibody is in some way related to the rheumatoid disease process, whether or not there be clinical evidence of salivary gland involvement. This is further emphasized in that, among RA patients, SDA was found significantly more frequently in older patients and those with more severe rheumatoid disease. Furthermore, $\mathrm{Sj}-\mathrm{RA}$ also occurred in patients who were older, had had their arthritis longer, and had more severe rheumatoid disease. Circumstantial evidence of lacrimal and salivary gland involvement by the rheumatoid process was provided by the significantly higher incidence of "possible" keratoconjunctivitis sicca and of symptomatic xerostomia noted in the SDA positive RA patients as compared with the RA patients without the antibody. This might suggest that a subclinical form of Sjøgren's disease was present in the SDA positive RA patients.

Histological evidence of salivary gland involvement in rheumatoid arthritis was provided by Waterhouse and Doniach (1966), who found focal lymphocytic sialadenitis in all of twelve females and in four of five males with rheumatoid arthritis. They considered the salivary lesion regularly found in rheumatoid arthritis to be Sjøgren's disease in miniature. It is thus perhaps not entirely surprising that, in rheumatoid arthritis, without clinical evidence of salivary or lacrimal gland involvement, there should be a high incidence of salivary duct antibodies.
The finding of a significantly lower incidence of SDA in the Sc patients than in the Sj-RA patients is of considerable interest. The previous detailed studies of Bloch and others (1965), Beck and others (1965), and Bunim and others (1964)-summarized in Table VII-have shown differences between these two sub-groups of Sjøgren's disease. Furthermore, Talal, Leventhal, and Waldorf (1966) found that lymphocytic transformation in response to phytohaemagglutinin and streptolysin was less in $\mathrm{Sj}-\mathrm{RA}$ than in Sc. However, with dinitrochlorobenzene skin sensitization, these workers found that differences between the two groups were not apparent. Reference to Table VII shows that, with the exception of anti-Gm factors, non-organspecific autoantibodies have been found to be consistently more prevalent in the Sc patients. It is therefore surprising that in our present studies in patients with Sc, which clinically appears to be an organ-specific disease, the possibly organ-specific SDA should be significantly less common than in the Sj-RA patients. The number of Sc patients is small in our series, but our findings, taken in conjunction with the observations of other workers, clearly indicate the need for a more detailed comparison of Sc patients and patients with salivary and lacrimal gland involvement accompanied by a connective tissue disorder.

\section{Summary}

(1) An immunofluorescent autoantibody to salivary duct epithelium has been found in two of thirteen patients with sicca syndrome, in eleven of seventeen patients with Sjøgren's disease and rheumatoid arthritis, and in 34 of 129 patients with uncomplicated rheumatoid arthritis.

TABLE VII

COMPARISON OF SICCA SYNDROME (Sc) WITH SJØGREN'S DISEASE WITH RHEUMATOID ARTHRITIS (Sj-RA) Bloch and others (1965) and Bunim and others (1964)

\begin{tabular}{|c|c|c|c|c|c|c|c|c|}
\hline \multicolumn{6}{|c|}{ Diagnosis } & Sc & $\mathbf{S j - R A}$ & Reference \\
\hline \multirow{2}{*}{\multicolumn{2}{|c|}{$\begin{array}{l}\text { Serum Globulin }(\mathrm{g} . / 100 \mathrm{ml} .) \ldots \\
\text { Antinuclear Factor } \quad \ldots\end{array}$}} & \multirow{2}{*}{$\cdots$} & \multirow{2}{*}{$\cdots$} & \multicolumn{2}{|c|}{$\begin{array}{l}\text { Mean } \\
\text { Range }\end{array}$} & \multirow{2}{*}{$\begin{array}{c}\begin{array}{c}4 \cdot 4 \\
2 \cdot 8-6 \cdot 8\end{array} \\
14 / 16(88 \%)\end{array}$} & \multirow{2}{*}{$\begin{array}{c}\begin{array}{c}3 \cdot 6 \\
2 \cdot 0-5 \cdot 7\end{array} \\
14 / 25(56 \%)\end{array}$} & \multirow{2}{*}{$\begin{array}{l}\text { Bloch and others (1965) } \\
\text { Bloch and others (1965) }\end{array}$} \\
\hline & & & & $\cdots$ & $\cdots$ & & & \\
\hline \multirow{3}{*}{\multicolumn{4}{|c|}{ Pattern of Nuclear Fluorescence Staining .. }} & \multicolumn{2}{|c|}{ Homogeneous } & $7 / 16$ & $8 / 18$ & \multirow[t]{3}{*}{ Bloch and others (1965) } \\
\hline & & & & \multicolumn{2}{|c|}{ Speckled } & $5 / 16$ & $2 / 18$ & \\
\hline & & & & \multicolumn{2}{|c|}{ Nucleolar } & $5 / 16$ & $0 / 18$ & \\
\hline \multicolumn{4}{|c|}{ Auto-immune Complement-Fixation Test .. } & $\cdots$ & $\cdots$ & $15 / 19$ & $5 / 26$ & Bloch and others (1965) \\
\hline \multicolumn{2}{|c|}{ Precipitating Autoantibodies } & $\ldots$ & - & . & $\ldots$ & $13 / 16$ & $1 / 18$ & Bloch and others (1965) \\
\hline Anti-Gm Factors & $\cdots$ & $\cdots$ & $\ldots$ & $\cdots$ & $\ldots$ & $4 / 20$ & $14 / 27$ & Bunim and others (1964) \\
\hline Reticulum Cell Sarc & $\mathrm{ma}$ & . & $\ldots$ & . & . & $4 / 23$ & $0 / 32$ & Bloch and others (1965) \\
\hline
\end{tabular}


(2) In patients with rheumatoid arthritis, the antibody was found significantly more frequently in older patients and in those with more severe rheumatoid disease.

(3) The antibody appears to be a manifestation of the rheumatoid disease process, in which other workers have shown a high incidence of chronic focal sialadenitis.

We wish to acknowledge financial support from the Arthritis and Rheumatism Council, and from the Research Funds of the University of Glasgow.

One of us (M.K.J.) was in receipt of a CIBA clinical research fellowship.

\section{REFERENCES}

Adams, J. F., Glen, A. I. M., Kennedy, E. H., Mackenzie, I. L., Morrow, J. M., Anderson, J. R., Gray, K. G., and Middleton, D. G. (1964). Lancet, 1, 401 (The histological and secretory changes in the stomach in patients with autoimmunity to gastric parietal cells).

Anderson, J. R., Goudie, R. B., Gray, K. G., and Buchanan, W. W. (1961). Scot. med. J., 6, 449 (Antibody to thyroglobulin in patients with collagen diseases).

—, Gray, K. G., Beck, J. S., Buchanan, W. W., and McElhinney, A. L. (1962). Ann. rheum. Dis., 21, 360 (Precipitating auto-antibodies in the connective tissue diseases). $-\frac{1}{\text { disease). }}$, and Kinnear, W. F. (1961). Lancet, 2, 456 (Precipitating auto-antibodies in Sjøgren's

Beck, J. S. (1961). Ibid., 1, 1203 (Variations in the morphological patterns of "autoimmune" nuclear fluorescence).

—, Anderson, J. R., Bloch, K. J., Buchanan, W. W., and Bunim, J. J. (1965). Ann. rheum. Dis., 24, 16 (Antinuclear and precipitating auto-antibodies in Sjøgren's syndrome).

Bertram, U., and Halberg, P. (1964). Acta allerg. (Kbh.), 19, 458 (A specific antibody against the epithelium of the salivary ducts in sera from patients with Sjøgren's syndrome).

Bloch, K. J., Buchanan, W. W., Wohl, M. J., and Bunim, J. J. (1965). Medicine (Baltimore), 44, 187 (Sjøgren's syndrome. A clinical, pathological and serological study of 62 cases).

Buchanan, W. W., Cox, A. G., Harden, R. McG., Glen, A. I. M., Anderson, J. R., and Gray, K. G., (1966). Gut, 7, 351 (Gastric studies in Sjøgren's syndrome).

Bunim, J. J., Buchanan, W. W., Wertlake, P. T., Sokoloff, L., Bloch, K. L., Beck, J. S., and Alepa, F. P. (1964). Ann. intern. Med., 61, 509 (Clinical, pathologic, and serologic studies in Sjøgren's syndrome. Combined Clinical Staff Conference at the National Institutes of Health).

Feltkamp, T. E. W. (1967). Personal communication.

Fulthorpe, A. J., Roitt, I. M., Doniach, D., and Couchman, K. (1961). J. clin. Path., 14, 654 (A stable sheep cell preparation for detecting thyroglobulin auto-antibodies and its clinical, applications).

Goudie, R. B., Macsween, R. N. M., and Goldberg, D. M. (1966). Ibid., 19, 527 (Serological and histological diagnosis of primary biliary cirrhosis).

Halberg, P., Bertram, U., Søborg, M., and Nerup, J. (1965). Acta med. scand., 178, 291 (Organ antibodies in disseminated lupus erythematosus).

Holborow, E. J., Brown, P. C., Roitt, I. M., and Doniach, D. (1959). Brit. J. exp. Path., 40, 583 (Cytoplasmic localization of "complement-fixing" autoantigen in human thryoid epithelium).

Jones, B. R. (1958). Lancet, 2, 773 (Lacrimal and salivary precipitating antibodies in Sjøgren's syndrome).

Park, W. M., and Mason, D. K. (1966). Radiology, 86, 116 (Hydrostatic sialography).

Ropes, M. W., Bennett, G. A., Cobb, S., Jacox, R. and Jessar, R. A. (1958). Bull. rheum. Dis., 9, 175 (1958 Revision of diagnostic criteria for rheumatoid arthritis).

Sjøgren, H. (1933). "A New Conception of Keratoconjunctivitis Sicca (Keratitis filiformis in hypofunction of the lachrymal glands)", trans J. B. Hamilton, 1943. Australasian Med. Publ. Co., Sydney.

Steinbrocker, O., Traeger, C. H. and Batterman, R. C. (1949). J. Amer. med. Ass., 140, 659 (Therapeutic criteria in rheumatoid arthritis).

Stoltze, C. A., Hanlon, D. G., Pease, G. L., and Henderson, J. W. (1960). Arch. intern. Med., 106, 513 (Keratoconjunctivitis sicca and Sjøgren's syndrome. Systemic manifestations and hematologic and protein abnormalities).

Talal, N. (1966). Bull. rheum. Dis., 16, 404 (Sjøgren's syndrome).

-, Leventhal, B. G., and Waldorf, D. S. (1966). Annual Meeting of the American Rheumatism Association. June 17-18, 1966, Denver, Colorado (Abnormal lymphocyte transformation and delayed hypersensitivity in certain patients with Sjøgren's syndrome). 
Walker, J. G., Doniach, D., Roitt, I. M., and Sherlock, S. (1965). Lancet, 1, 827 (Serological tests in diagnosis of primary biliary cirrhosis).

Waterhouse, J. P., and Doniach, I. (1966). J. Path. Bact., 91, 53 (Post-mortem prevalence of focal lymphocytic adenitis of the submandibular salivary gland).

Williamson, J., and Allison, M. (1967). Brit. J. Ophthal., 51, 596. (The effect of temperature and humidity on the Schirmer tear test).

—, Cant, S., Mason, D. K., Greig, W. R., and Boyle, J. A. (1967). Ibid., 51, 721 (Sjøgren's syndrome and thyroid disease).

L'occurrence de l'anticorps contre l'épithélium du canal salivaire dans la maladie de Sjegren, l'arthrite rhumatismale et dans d'autres arthritides; étude clinique et de laboratoire

\section{RÉSUMÉ}

(1) On trouva un anticorps immunofluorescent contre l'épithélium du canal salivaire chez deux sur treize malades atteints de syndrome sicca, chez onze sur dix-sept patients atteints de maladie de Sjøgren et d'arthrite rhumatismale et chez 34 sur 129 patients atteints d'arthrite rhumatismale sans complications.

(2) Pour l'arthrite rhumatismale, l'anticorps fut trouvé bien plus souvent chez des malades plus âgés et chez ceux dont la maladie rhumatismale fut plus sévère.

(3) L'anticorps semble être une manifestation du processus morbide rhumatismal dans lequel d'autres auteurs ont démontré une grande fréquence de la sialadénite focale chronique.
La ocurrencia del anticuerpo contra el epitelio del cnnducto salivario en la enfermedad de Sjegren, la artritis reumatoide $y$ en otros artritidicos; estudio clínico y de laboratorio

\section{SUMARIO}

(1) Un anticuerop inmunofluorescente contra el epitelio del conducto salivario fué encontrado en dos de trece enfermos con síndrome sicca, en once de diecisiete pacientes con enfermedad de Sjøgren y artritis reumatoide y en 34 de 129 pacientes con artritis reumatoide sin complicaciones.

(2) Respecto a la artritis reumatoide, el anticuerpo fué encontrado con frecuencia significativamente mayor en enfermos más viejos y en casos de enfermedad reumatoide más grave.

(3) El anticuerpo parece representar una manifestación del proceso morboso reumatoide en el cual otros autores han encontrado una frecuencia aumentada de la sialadenitis focal crónica. 